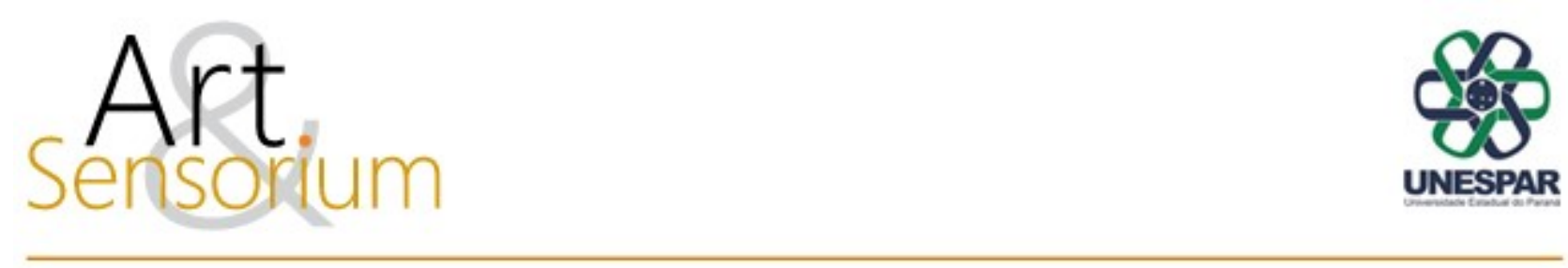

\title{
TRANSFIGURAÇÕES DE UM PERSONAGEM ESCULTÓRICO NOS MEIOS IMPRESSOS: O MONUMENTO A TIRADENTES, DE JOÃO TURIN
}

\author{
DOI: https://doi.org/10.33871/23580437.2021.8.2.169-188
}

Larissa Busnardo ${ }^{1}$

\begin{abstract}
Resumo: Este artigo trata dos significados que permeiam o trânsito de uma imagem no tempo, com enfoque nas possíveis apropriações da linguagem escultórica pelos meios impressos, a partir das reproduções da obra Tiradentes, de João Turin. Em Curitiba, esse artista consagrou-se com a promoção de ideais paranistas e elaborou uma estatuária pública em homenagem a mártires históricos nacionais. A circulação de notícias e reproduções do monumento ao inconfidente em periódicos ilustrados, na década de 1920, foi fundamental para a construção de memórias e narrativas políticas. Propõe-se então a traçar uma biografia desse personagem de bronze, identificando possíveis interrelações entre fotografia e escultura a partir das reflexões teóricas de Michel Frizot, e também em aproximação à abordagem de Ana Maria Mauad acerca da análise histórica de imagens na cultura visual.
\end{abstract}

Palavras-chave: Escultura; Fotografia; Meios impressos; João Turin; Tiradentes.

\section{TRANSFIGURATIONS OF A SCULPTURAL CHARACTER ON PRINTED MEDIA: THE MONUMENT TO TIRADENTES, BY JOÃO TURIN}

Abstract: This paper intends to observe the meanings that permeate the transit of an image in time, focusing on the possible appropriations of sculptural language by printed media based on reproductions of the sculpture Tiradentes, by João Turin. In Curitiba, this artist became consecrated with the promotion of regional paranist ideals and also elaborated a public statuary in honor of national historical martyrs. The circulation of news and reproductions of the monument to the inconfident in illustrated periodicals, in the 1920s, was fundamental for the construction of memories and political narratives. The proposition is then to trace a biography of this bronze character, identifying possible interrelationships between photography and sculpture based on Michel Frizot's theoretical reflections, and also in an approach to Ana Maria Mauad's method to the historical analysis of images in visual culture.

Keywords: Sculpture; Photography; Printed media; João Turin; Tiradentes.

\section{TRANSFIGURACIONES DE UN PERSONAJE ESCULTÓRICO EN LOS MEDIOS IMPRESOS: EL MONUMENTO A TIRADENTES, DE JOÃO TURIN}

Resumen: Este artículo aborda los significados que permean el tránsito de una imagen en el tiempo, centrándose en las posibles apropiaciones del lenguaje escultórico por los medios impresos, a partir de

\footnotetext{
${ }^{1}$ Doutoranda em História na linha Arte, Memória e Narrativa, UFPR (Curitiba, Paraná). Bolsista CNPq. Mestra em História pela UFPR. Especialista em História Cultural, pela UTP. Professora e artista visual pela Faculdade de Artes do Paraná (UNESPAR). Pesquisadora na área da Fotografia e seus entremeios com outras linguagens visuais. Currículo Lattes: lattes.cnpq.br/1690886300255067. Orcid: orcid.org/0000-0002-1605-3356. E-mail: lara.busnardo@gmail.com.
} 
reproducciones de la obra Tiradentes, de João Turin. En Curitiba, este artista se consagró con la promoción de los ideales regionales paranistas elaboró una estatuaria pública en honor a mártires históricos nacionales. La circulación de noticias y reproducciones del monumento al mártir inconfidente en publicaciones periódicas ilustradas, en la década de 1920, fue fundamental para la construcción de memorias y narrativas políticas. Se propone trazar una biografía de este personaje de bronce, identificando posibles interrelaciones entre fotografía y escultura a partir de las reflexiones teóricas de Michel Frizot, y también en una aproximación al método de Ana Maria Mauad para el análisis histórico de las imágenes en la cultura visual.

Palabras clave: Escultura; Fotografía; Medios impresos; João Turin; Tiradentes.

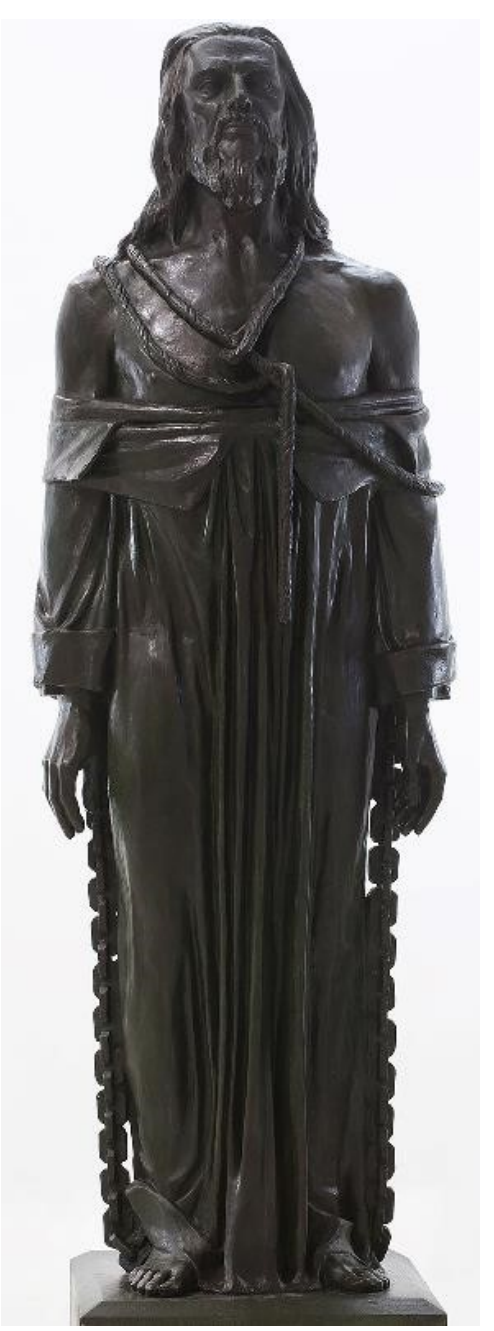

Figura 1: João Turin, Tiradentes, 1922. Escultura em bronze, 230 x 60 x $42 \mathrm{~cm}$. Praça Tiradentes. Foto do Acervo João Turin, Curitiba.

\section{Introdução}

O monumento a Tiradentes, realizado pelo escultor paranaense João Turin (1878-1949), foi inaugurado em Curitiba no dia 21 de abril de 1927, na movimentada Praça Tiradentes, pela ocasião das comemorações do Cinquentenário da Imigração Italiana, combinada ao feriado nacional de Tiradentes. A instalação dessa obra escultórica no espaço público ocorreu junto a uma sequência de outras inaugurações de monumentos em Curitiba, em um contexto de invenção da identidade regional paranaense, sobretudo por meio da exploração simbólica de personagens históricos idealizados. Nesse sentido, o papel do artista era fundamental ao materializar em bronze as memórias, orgulhos e paixões 
associados aos interesses políticos e ideológicos vigentes.

Tornado um personagem heroico pelos republicanos, Tiradentes foi amplamente retratado, por muitos artistas, quase sempre com inspiração nas imagens dos mártires, a exemplo dos ídolos da Revolução Francesa, ou mesmo das representações cristãs da Paixão. Com a apropriação dessa mesma narrativa iconográfica, a escultura de Turin inseriu-se com notoriedade no cenário curitibano, especialmente ao ser reproduzida em fotografias nas páginas dos meios impressos, como a revista carioca de grande circulação O Malho; a Illustração Paranaense, editada pelo fotógrafo João Baptista Groff (18971970); e o jornal O Dia, que ofereceu visibilidade apoteótica ao evento de inauguração e ao discurso ufanista de culto sobre a figura desse personagem tornado mártir nacional.

No processo de industrialização e consumo da produção imagética, a fotografia e as revistas ilustradas tiveram papel fundamental para a circulação de obras de arte, conforme teorizado por Walter Benjamin (2012). No contexto da reprodutibilidade técnica, imagens que seriam concebidas por instituições e agentes culturais com alto valor de culto passavam, por intermédio do registro fotográfico, a apresentar também uma ampliação do seu valor de exposição, modificando a relação com o observador. Inclui-se nessa conjuntura a reprodução de imagens escultóricas, pois, apesar da impossibilidade do seu volume e materialidade serem completamente apreendidos através de figuras bidimensionais em papel, a presença múltipla de registros em perspectivas diversas propunha ao observador moderno a apreensão de uma nova experiência sobre o tridimensional. Nesse sentido, o processo de circulação dessas imagens estava atrelado à ampliação das percepções multifacetadas do escultórico por meio do fotográfico. Este processo é tratado também em Jonathan Crary a partir do estudo histórico da visão.

Segundo a proposição de Crary (2012), o observador é um produto histórico e um lugar ativo de práticas, técnicas e procedimentos de subjetivação. Após a reformulação científica da percepção visual, compreendeu-se que a experiência moderna da atenção ocorre de forma fragmentária e depende da participação contínua de um sujeito no tempo para que se constitua uma ideia visual. Esse observador moderno, que opera a visão de forma individual e em movimento, pode dispor de uma multiplicidade de reproduções do entorno de uma figura escultórica, por exemplo, e recompor sua impressão pessoal sobre a matéria tridimensional. Esta teoria é corroborada por Michel Frizot (2014) em ensaios sobre as aproximações entre escultura e fotografia. Ele observa que a reprodutibilidade da imagem técnica oferece condições para múltiplas apreensões do escultórico, pois nós, observadores, transformamos mentalmente o objeto fotográfico em escultura: "a capacidade escultural é a capacidade da visão humana, do olhar humano, que pode operar com base em fotografias e em todos os tipos de dados fotográficos, desde que estes forneçam as informações necessárias para sua ativação mental" (FRIZOT, 2014, p.65, tradução nossa) ${ }^{2}$. Assim, acumulando fragmentos de informações visuais, o observador é capaz de completar uma imagem mental que reconstrói subjetivamente sobre o entorno de uma escultura:

Uma escultura é melhor compreendida ao ser percebida a partir de diferentes pontos no espaço e em uma série de pontos de vista espalhados ao longo do tempo, e é através desse processo de visualização que a escultura passa a existir. Mas a visão humana não é apenas trabalho do olho, é inseparável da atividade reconstrutiva do cérebro; a visão é ocular e mental. Como resultado, a escultura também é uma cosa mentale, uma reconstrução mental, mesmo que apenas por causa da atividade visual prolongada que ela exige. A escultura não pode ser apreciada como uma obra exceto através de sucessivas percepções visuais, em espaço e luz, através do acúmulo mental de déjà-

\footnotetext{
${ }^{2}$ No original: "Sculptural capacity is the capacity of human vision, of the human gaze, which can operate on the basis of photographs and all kinds of photographic data, so long as these provide the necessary information for its mental activation". Uma breve ressalva quanto às abordagens de Frizot: Nesse texto, o autor está preocupado exclusivamente com a função da visão na percepção. No entanto, seria relevante aprofundar em outras abordagens a contribuição da percepção tátil (não ocular), que é central para a apreensão da tridimensionalidade. Este ponto não é o foco de seus estudos.
} 
vus anteriores. A escultura apenas é escultura através da intervenção da visão, que lhe confere qualidades espaciais, formais e dinâmicas, e por isso está sujeita aos requisitos e limitações da visão ocular. (FRIZOT, 2014, p.57, tradução nossa) ${ }^{3}$

Neste artigo, a compreensão histórica das imagens analisadas inspira-se nas proposições teóricas que tratam sobre as particularidades dos objetos escultóricos na percepção do observador moderno, e, notadamente, as possíveis aproximações entre a escultura e a fotografia. Parto do entendimento de que entre as imagens ocorre uma relação de intermedialidade, ou seja, uma consciência de disputas, interconexões e consecutivos trânsitos de significações. Para tanto, consideram-se duas diferentes experiências: uma que é direta, entre o fotógrafo e a obra; e outra que é mediada pela tradução fotográfica em papel, possibilitada pelo consumo de reproduções que circulam em impressos ilustrados.

Nessa abordagem sobre as imagens e suas transfigurações históricas pela via fotográfica, compartilho dos procedimentos de Ana Maria Mauad no texto Como nascem as imagens? Um estudo de história visual. A partir de uma reflexão sobre o aparecimento e trajetória da figura da flor como símbolo da Anunciação na cultura visual, ela dialoga com Walter Benjamin e Hans Belting para propor uma análise da fotografia como um arquivo mediador, onde se encontram escondidas e engendradas as memórias mudas de outras imagens e outros observadores antepassados.

Proponho uma abordagem que se apoia na noção de que todas as imagens possuem uma biografia, que ensejam trajetórias nem sempre lineares, o que implica afirmar que não existe uma história por detrás das imagens, mas imagens que fazem história. Assim, gostaria de refletir sobre o nascimento de uma imagem e, por meio da sua trajetória, problematizar a ordem dos tempos históricos (MAUAD, 2014, p.109)

Em sua abordagem, a autora discorre, portanto, sobre a possibilidade de um estudo do trânsito e vida social das imagens, corporificadas e ritualizadas por meio de práticas históricas. Pois, concluiu, as imagens são nômades (2014, p.117). Com essa perspectiva, ela observa uma contínua "reciclagem" dos sentidos das imagens, como símbolos vivos e dispostos a "acamparem em corpos diferentes e se tornarem novas imagens em novos processos de simbolização" (MAUAD, 2014, p.115). É nesta perspectiva, enfim, que me proponho a investigar por quais caminhos sucedeu-se o trânsito cultural e simbólico do personagem escultórico de Tiradentes, realizado por João Turin, a partir das suas transfigurações em fotografias.

\section{Tiradentes, do gesso ao bronze: uma escultura sobrevivente}

Em 1911, com o término dos estudos como bolsista na Academia de Belas-Artes de Bruxelas, o paranaense João Turin decidiu residir em Paris. Entretanto, de acordo com a narrativa de Elisabete Turin (1998), quando chegou à cidade o escultor teve dificuldades para se estabelecer e conseguir encomendas. Além disso, o fato de ser um estrangeiro o fazia alvo constante de desconfiança por parte dos franceses. Foi após sua premiação na Exposição Universal de 1913, em Gante, que as perspectivas profissionais começaram a melhorar para Turin. Naquela época, fez em parceria com Zaco Paraná (1884-1961) alguns monumentos por encomenda a partir de fotografias enviadas pelos seus comitentes brasileiros, e teve bem-sucedida participação no famoso Salon des Artistes Français,

\footnotetext{
${ }^{3}$ No original: "A sculpture is better understood for being perceived from different points in space and in a series of points of view spread out over time, and it is through this viewing process that the sculpture comes into being. But human vision is not just the work of the eye, it is inseparable from the reconstructive activity of the brain; vision is ocular and mental. As a result, sculpture is also a cosa mentale, a mental reconstruction, if only because of the prolonged visual activity it requires. Sculpture cannot be appreciated as a work except through successive visual perceptions, in space and light, through the mental accrual of previous 'déjà-vus'. Sculpture is only sculpture through the intervention of vision, which gives it its spatial, formal and dynamic qualities, and because of this it is subject to the requirements and limitations of ocular vision."
} 
principalmente na edição de 1922, com a obra Tiradentes (TURIN, 1998). Sublinha-se que a presença do escultor nos salões franceses passou a ser acompanhada pelos envaidecidos periódicos paranaenses, também por meio do intercâmbio fotográfico.

Com o reconhecimento de suas habilidades profissionais, mas também por intermédio da divulgação de suas realizações nas páginas da imprensa, a situação de Turin se ajustou gradativamente em Paris, possibilitando que ele dividisse um ateliê em Montparnasse com o pintor conterrâneo João Ghelfi. Seu novo endereço na Rua Vercingetórix avizinhava movimentados cafés e gabinetes de importantes intelectuais, literatos e marchands contemporâneos a ele - como a influente Gertrude Stein - atelieres e exposições de vários escultores modernos proeminentes - como Rodin, Bourdelle e Brancusi tendo inclusive a oportunidade de conviver com alguns desses profissionais e conhecer suas obras pessoalmente (TURIN, 1998). Algumas situações potencializavam essa rede de sociabilidades entre Turin e os outros artistas em Paris, como as frequentes reuniões nos cafés locais e os encontros nas comunidades de grupos imigrantes. Na comunidade dos italianos, por exemplo, aponta-se um possível contato entre ele e Modigliani (LEITE, 2014, p.40). Já em relação à comunidade de brasileiros, sabese que Turin conheceu os jovens artistas Eliseu Visconti e Victor Brecheret, por exemplo.

Vale considerar brevemente a peculiaridade do encontro entre Turin e Brecheret (1894-1955), descrita por Teixeira Leite (2014). Contemplado por uma pensão do governo paulista, o jovem Brecheret viria a conhecer Turin em Paris, em 1921, por meio de um grupo de amigos em comum. A convivência de poucos meses foi suficiente para que o paranaense, quando decidira retornar brevemente ao Brasil (ou assim imaginava), em 1922, cedesse seu ateliê ao escultor paulista, com a contrapartida de que o jovem tomasse conta dos seus preciosos trabalhos até seu retorno. Deste modo, durante algum tempo, foi no ateliê do Turin que Brecheret exerceu a atividade de escultor e recepcionou seus camaradas modernistas, como Tarsila do Amaral e Di Cavalcanti. No entanto, em destino contrastante ao que sucederia para João Turin, Brecheret recebeu uma herança em 1924, e decidiu deixar o espaço do amigo para montar um ateliê próprio no Brasil, o qual administraria paralelamente a um novo endereço parisiense. Depois retornou em definitivo a São Paulo, em 1932, antes de vir a participar da fundação da Sociedade Pró-Arte Moderna (AMARAL, 1998, p.248).

A ocupação daquele ateliê em Montparnasse foi sucedida por diferentes artistas, enquanto Turin, preocupado, teve a sua intenção de retornar frustrada por uma série de impedimentos e fatores políticos (como a crise econômica de 1929, por exemplo, sucedida pelo golpe varguista), até que, desistindo, passou a trabalhar com esforço para tentar ao menos resgatar as obras que havia deixado para trás. Finalmente, em 1935, recebeu a notícia de que estavam a caminho as poucas peças que restaram. Porém, ao chegarem no Brasil, as esculturas ficaram retidas pela burocracia nas alfândegas dos portos de Santos e Paranaguá por mais um ano, até que pudessem enfim ser retiradas pelo artista - com muita decepção, pois as peças em gesso não resistiram aos danos acumulados após tanto tempo em mau acondicionamento. Desta forma, de toda a produção realizada por João Turin na Bélgica e na França, restaram apenas os registros fotográficos, além de poucas esculturas remanescentes que haviam sido previamente encomendadas ou enviadas para exposição (LEITE, 2014).

Dentre as raras obras sobreviventes daquele período da trajetória artística de Turin, focaliza-se o caso da estátua "Tiradentes". A obra recebeu elogios em jornais como o Le Brésil após sua participação no Salon francês (LEITE, 2014, p.44). O êxito obtido com essa escultura teria funcionado como incentivo para o artista retornar ao Brasil, com sua versão do personagem, e participar de um importante evento artístico ocorrido na Escola Nacional de Belas Artes do Rio de Janeiro em 1922: O Salão Internacional de Belas Artes, que integrava as festividades do Centenário da Independência. É digno de nota que, apesar de comumente preterido pela historiografia, este foi o maior evento republicano do início do século XX, organizado com o objetivo de manifestar a modernização do país e afirmar uma identidade nacional (SANT'ANA, 2008). Assim como inúmeros outros artistas brasileiros e estrangeiros, Turin fora atraído a inscrever-se naquela grande vitrine, especialmente pela promessa da aquisição de obras que se referissem à história nacional. E é plausível que tenha sido 
justamente esta a motivação para a escolha de representar a figura de Tiradentes.

$\mathrm{Na}$ exposição, o escultor foi premiado pelo júri com menção honrosa ${ }^{4}$, mas sua obra não foi adquirida, e a participação rendeu uma crítica tenaz de Adalberto de Mattos na revista carioca $O$ Malho:

Quem entra na galeria onde estão grupados os trabalhos dos nossos esculptores, sente o olhar attrahido por uma grande figura hirta como um fantasma: é um Tiradentes firmado por João Turim [sic]. É com verdadeira dor que se observa o desperdício de tanto gesso e de tanto trabalho! O autor da estátua, pretendeu, naturalmente, crear um typo novo, que empolgasse o espectador e elevasse o martyr acima do corriqueiro em que caiu, [...] não $h a$ principiante que não tenha apolegado pelo menos uma cabecinha da figura sympathica e decorativa do alferes enforcado de $1790 \ldots$ O Sr. João Turim, apezar de estar em Paris, não se quiz furtar à regra geral, modelou também um Tiradentes, mas um Tiradentes horrível [...]. A estátua tem uma 'qualidade', conseguiu se destacar entre os demais trabalhos pela ruindade. (MATTOS in: O Malho, 23/12/1922, p.43)

Bastante embravecido com a recepção na "panela do Rio", como chamava o cerrado círculo artístico da capital, Turin respondeu com uma carta aberta debochada, onde ironizou: "se eu tivesse, para satisfazer ao Sr. Matinhos, feito um Tiradentes-tenor, cantando il sole mio, hein, Sr. Matos, que elogios, que frases não teriam saído de sua dourada pena" (LEITE, 2014, p.56). Talvez a resposta tenha funcionado para o propósito do artista, pois posteriormente, em seus manuscritos, anotou que o crítico o "ajudou muito" ao escrever que seu Tiradentes era um "trabalho muito digno" (TURIN, 19--, $\mathrm{n}^{\mathrm{o}}$ 775). De qualquer modo, a passagem inspira reflexões sobre a trajetória percorrida pela obra entre a exposição no Salon, a instalação na praça e a recepção pelos agentes culturais paranaenses. Que outros significados estariam por trás da transformação dessa imagem em monumento?

\section{A estatuamania paranista e o culto ítalo-brasileiro aos nacionalismos}

Na década de 1920, João Turin realizou uma série de obras escultóricas que foram instaladas nas praças de Curitiba como monumentos públicos, em homenagem, essencialmente, a personagens históricos nacionais e regionais transformados em heróis. Encomendadas por comitês especiais, as inaugurações dessas obras era sempre um pretexto para a realização de cerimônias cívicas imponentes, em que, de forma ritualizada, a população prestava reverências ufanistas a símbolos politicamente inventados. As figuras enaltecidas eram estipuladas com intenções pedagógicas, a favor dos ideais paranistas que estavam sendo traçados naquele contexto, e tudo isso merecia espaço privilegiado em todas as mídias impressas. Esse momento de conversão dos espaços públicos da cidade em palcos de rituais ideológicos foi apelidado por Luís Fernando Lopes Pereira de "estatuamania paranista", no qual "seguindo os princípios positivistas se cria uma espécie de religião cívica onde a população passa a interagir e a abraçar os ideais de ordem, progresso, civilização" (PEREIRA, 1996, p.201). Em especial, as obras alocadas na praça Tiradentes nos apresentam a projeção do tipo ideal de República defendida pelos paranistas: de ideologia positivista, anticlerical, e política conservadora (PEREIRA, 1996, p.202).

O Paranismo foi um movimento cívico-cultural que se desenvolveu em Curitiba, do fim do século XIX até a metade do século XX, notadamente a partir das proposições ideológicas do intelectual Romário Martins (1874-1948). Paralelamente às políticas hipernacionalistas do contexto, tal ideário insuflava uma suposta identidade singular ao paranaense, baseada na valorização de elementos considerados próprios ao território regional, como a araucária, o pinhão, e a miscigenação populacional com os imigrantes europeus (como pode-se constatar, essa proposta não contemplava a

\footnotetext{
${ }^{4}$ Informações sobre a premiação podem ser conferidas em: O Malho. №1059. Rio de Janeiro, 30 Dez. 1922, p.46.

5 Termo inspirado no conceito do autor francês Maurice Agulhon, desenvolvido em “La 'statuomanie' et l'histoire”, 1988.
} 
população negra). Era também incorporada ao componente ideológico uma discussão estética, de forma que a intelectualidade local agiria não apenas para a criação de uma identidade política - com o objetivo de inculcar valores e normas de comportamento morigerados, idealizados e institucionalizados - mas também, ao mesmo tempo, de símbolos e tradições até então inexistentes, especialmente por meio da atividade colaborativa de agentes culturais (PEREIRA, 1996, p.82), como foi o caso de João Turin.

As festividades em inaugurações abrangiam a integração de trabalhos correlacionados aos monumentos, com a participação de múltiplos agentes culturais. O evento costumava ser reiterado e potencializado inclusive com a ação paralela de profissionais responsáveis por fazer circular imagens, a exemplo dos fotógrafos jornalísticos, como João Baptista Groff, e do gravador e cunhador José Peón ${ }^{6}$, que confeccionou as medalhas comemorativas distribuídas em homenagem à inauguração do monumento a Tiradentes (Figura 2).

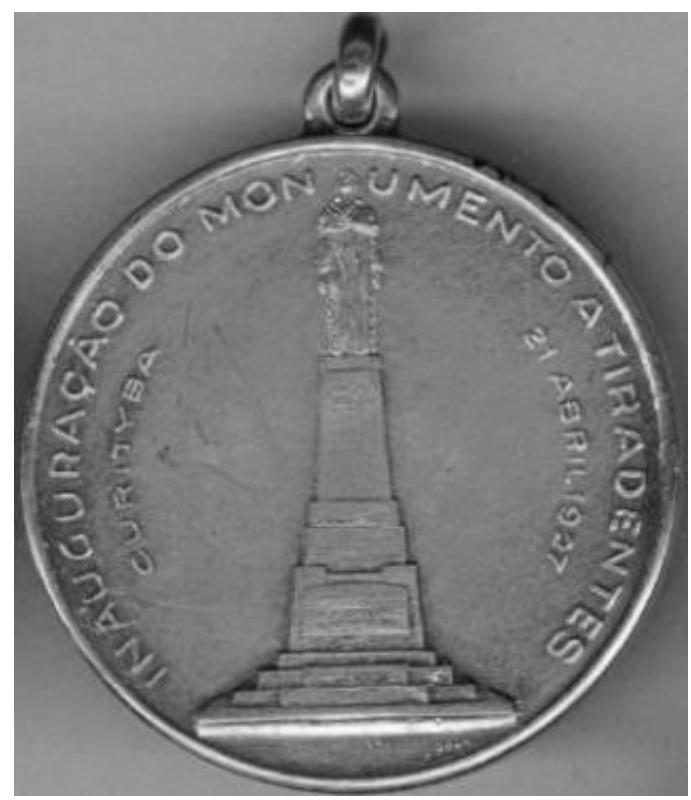

Figura 2: José Peón, Medalha comemorativa do monumento a Tiradentes, 1927. 3 cm. Museu Paranaense.

Foi nesse bojo que, em 1927, a colônia italiana do Paraná decidiu realizar, na ocasião do Cinquentenário da Imigração Italiana, a encomenda de um monumento em tributo ao "mártir da liberdade", Tiradentes, como "uma demonstração eloquente da grande amizade pela terra, patria de seus filhos e de seus nettos, por cujo engrandecimento tanto ella trabalhou" - lê-se no jornal Diário da Tarde (21/04/1927, p.1). Para tanto, ainda em fevereiro daquele ano o consulado emitiu uma nota em italiano na imprensa, convocando a comunidade a colaborar com os preparativos (O Dia, 19/02/1927, p.5). Depois, publicaram também um convite para a cerimônia pública, reforçando especificamente a importância da presença italiana no evento (O Dia, 17/04/1927, p.4).

A escolha dos italianos para a data da homenagem não se deu ao acaso. O feriado do Dia de Tiradentes foi instituído logo após a Proclamação da República, em 1890 - e ambos os momentos, tanto da execução do inconfidente Joaquim José da Silva Xavier, como do golpe republicano em si, configurariam, igualmente, fortes símbolos nacionais (DOLCI, 2014, p.132). Coincidentemente, todavia, a mesma data marcava um acontecimento político significativo também na Itália, pois no dia 21 de abril é celebrado o aniversário da fundação de Roma. A conjunção das duas comemorações em Curitiba foi proposital e se tornou o principal mote de algumas matérias nos jornais, a exemplo da

\footnotetext{
${ }^{6}$ José Peón (1889-1972) era argentino, professor de gravura na Escola de Música e Belas Artes e atuou na produção de itens de numismática de 1914 a 1969. Foi responsável pela cunhagem de diversas placas que integram os monumentos escultóricos da cidade e há grande acervo de suas medalhas no Museu Paranaense.
} 
capa de $O$ Dia, que trazia as manchetes "A Italia livre ao Brasil livre" e "Natal de Roma e victoria de Tiradentes". Estas emolduram o esforço narrativo feito pelo articulista quando relacionou os lemas da Inconfidência Mineira (Libertas Quae Sera Tamen), da Revolução Francesa (Liberté, Egalité, Fraternité), e da resistência romana contra os sabinos (Senatus Populusque Romanus), na tentativa de expressar sua devoção pessoal ao mártir. Ao final da argumentação, aproveitou para lembrar que o escultor do monumento em questão era também um cidadão ítalo-brasileiro:

Roma - a possante rainha do mundo antigo que fecundou a civilização ocidental como continuadora do Oriente e da Grécia - e Tiradentes - o emblema, filho da Revolução Franceza - não puderam encontrar melhor executor da idéa ou da amizade espiritual da Colônia Italiana, do que o cinzel e talento de João Turin. (O Dia, 21/04/1927, p.1)

De acordo com a análise de Geraldo Leão, atos como a inauguração de monumentos, que transformavam a cidade com vistas a comemorações grandiosas, inscreviam-se em uma política de essência simbólica nacionalista, e eram sempre "construídos e pensados segundo a lógica do poder vigente, para difusão e fixação de seus pontos de vista" (CAMARGO, 2005, p.63). Nesse sentido, os positivistas foram de grande influência para a definição desses significados nas imagens cívicas, e impuseram suas versões heroicas para fatos históricos em diversos personagens-monumento, formando uma comunidade imaginada que se identificava e solidarizava com estes ideais em comum. $\mathrm{O}$ autor reforça, ainda, a influência das doutrinas fascistas, muito presentes no período, para a formulação dessas relações políticas com a memória imagética coletiva (CAMARGO, 2005, p.79). No caso dos paranistas, como mencionado, essas tradições convergiam-se aos elementos identitários regionais, construídos sob ideário muito similar ao nacionalista, e por vezes adotavam-se os heróis nacionais como regionais e os regionais como nacionais.

Pois bem, se a noção da coletividade formada no entorno de fatores em comum - étnicos, geográficos e culturais - são bases fundamentais dos nacionalismos no século XX (VELLOSO; OLIVEIRA; GOMES, 1982, p.26), é importante pontuar que, para os grupos descendentes de imigrantes que residiam no Paraná, como os italianos, havia a somatória potencial de uma tripla construção identitária. Além de exercitarem as tradições próprias de sua cultura original, também demonstravam orgulho de sua assimilação aos costumes brasileiros e, por fim, dos princípios paranistas engendrados nos atos da sociedade receptora. Isto é particularmente evidente no caso da inauguração do monumento a Tiradentes, pois, como pode-se observar na descrição celebrativa de $O$ Dia, diversos elementos de caráter nacionalista podem ser identificados entre os discursos veiculados.

É já propriedade do povo do Paraná [...] a generosa dádiva de civismo e amizade que a illustre e esforçada Colonia Italiana offerecem como recordação indelevel do amor fraterno que liga as duas Patrias. O dia todo, póde-se dizer, foi de [...] romaria e homenagem ao grande Martyr. [...] O presidente do Estado, assistido das altas autoridades presentes, dirigiu-se ao monumento, descerrando o velario, que era composto das côres italo-brasileiras, e inaugurando a estatua, sob fragorosa salva de palmas, e aos sons imponentes do hymno nacional brasileiro e do hymno nacional ataliano [sic]. [...] A mais franca alegria se tornava visivel na massa popular, que soube tão alta e bellamente comprehender a sagrada intenção [...]. A estátua é de bello effeito esculptural e architetonico, severa, hieratica, sóbria. (O Dia, 22/04/1927, p.1)

Para além da conjunção de datas das comemorações cívicas brasileira e italiana, outros fatores descritos da cerimônia de inauguração demonstram a colaboração entre imigrantes e receptores e a identificação entre seus ideários, como a indicação de um possível "amor fraterno que liga duas pátrias", a composição do velário com as "cores ítalo-brasileiras" e a execução consecutiva dos hinos de ambos os países. Não é irrelevante mencionar a descrição dos italianos como esforçados, uma 
característica que reforça a suposta função social de seu grupo étnico, segundo os ideais paranistas: o trabalho campesino. Portanto, o evento realizado em homenagem ao "mártir" nacional, foi considerado nas páginas do jornal como o resultado de uma intenção "sagrada" e do trabalho patriótico do "povo do Paraná". Termos como estes, que associam o martírio à trajetória de Tiradentes, aparecem também em outros momentos no mesmo jornal.

Contudo, é importante frisar, nem todos concordavam com essa veneração a Tiradentes ou com a instalação do monumento em sua homenagem - o que, como já observado, compunha um projeto político paranista. No jornal Diário da Tarde, por exemplo, foi publicada uma crítica à decisão da Prefeitura de remover as árvores da Praça Tiradentes para a instalação da estátua do "pseudo mártir":

a Prefeitura [...] resolveu botar abaixo toda a arborização da Praça Tiradentes. É o que se pode concluir do afan com que seus empregados estão impiedosamente a metter o machado nas velhas arvores [...] não podemos deixar de condemnar esse seu acto de lesa-esthetica [...]. Não applauriremos tambem o seu acto, si é sua a intenção de abrir apenas uma clareira afim de collocar ali o monumento de Tiradentes. Será isso um erro, porque quebrará a feição symetrica da Praça [...]. E mesmo si a collocação do monumento ao pseudo martyr da Inconfidencia Mineira, exige o sacrificio daquellas antiquissimas eugenias, então trate-se de collocar esse monumento em outro logar ou de remover a estatua de Floriano [...]. Naturalmente apparecerão os passadistas, os conservadores das taes tradições gritando contra esse crime nefando de lesa-passadismo. (Diário da Tarde, 15/03/1927, p.2)

O autor manifestou sua consciência pessoal sobre as questões políticas então envolvidas e deixou evidente que havia um conflito entre as posições higienistas e urbanísticas sobre o que deveria ser feito na praça, contra as decisões do grupo que chamou de "passadistas" - os quais, na sua opinião, estavam mais preocupados em demonstrar "o amor ao passado", ou seja, o culto festivo aos heróis republicanos, do que em preservar a arborização ali existente. A crítica, apesar de incisiva, bate de frente com as narrativas preponderantemente positivas dos periódicos locais, e não reflete o posicionamento demarcado por intelectuais e agentes culturais paranistas, mais influentes naquele momento e muito entusiasmados com as festividades ufanistas. E, como veremos, as reproduções fotográficas do mártir esculpido por Turin colaborariam com o propósito de reforçar os discursos românticos da imprensa sobre o mito nacionalista.

\section{A circulação da imagem escultórica por meio de fotografias impressas}

A exposição da escultura de Turin na imprensa durante o processo de instalação do monumento a Tiradentes foi extensiva e abarca um conjunto de posições políticas. Para além das reportagens textuais, os periódicos veicularam também muitas imagens: retratos do escultor, fotografias do monumento erigido, do momento de sua inauguração e mesmo reproduções de outras obras de arte que dividiam a mesma temática e imaginário.

No contexto industrial, as reproduções fotográficas tornaram-se informações cotidianas e numerosas nas páginas dos impressos, geralmente lidas de forma cada vez mais apressada e superficial, gerando uma "relação contínua entre as imagens que já existem em nossas mentes e aquilo que imagens externas ampliam, acrescentam ou potencializam em nossos juízos" (KAMINSKI, 2012, p.271). Quando Walter Benjamin apontava para uma mudança no sistema perceptivo com a fotografia, ao utilizar-se da ideia de inconsciente ótico, ele apontava que a reprodutibilidade técnica possibilitava outra forma de aproximação e experiência em relação à imagem, pois esta revelava detalhes antes ignorados pelo observador:

[a reprodução técnica] pode salientar aspectos do original que não são acessíveis ao

R. Inter. Interdisc. Art\&Sensorium, Curitiba, v.8, n.2, p. 169 - 188 Jul.- Dez. 2021 
olho humano, mas somente à objetiva ajustável, capaz de escolher livremente determinados ângulos; ou, com a ajuda de certos métodos, como as lentes de aumento ou a câmera lenta, pode capturar imagens que escapam inteiramente à visão natural. [...] aproxima o original do espectador [...]. A cada dia torna-se mais irrecusável a necessidade de chegar o mais perto possível do objeto por meio de sua imagem, ou melhor ainda, por meio de sua cópia (BENJAMIN, 2012, p.14)

Por outro lado, Jonathan Crary propõe que um tipo diferente de visão foi reformulado historicamente, por meio de um novo conjunto de práticas sociais, saberes e relações com o corpo. Com o rompimento de modelos clássicos da percepção, o observador moderno desenvolveu técnicas inéditas, tornando-se capaz não apenas de consumir enormes quantidades de imagens, mas também de produzir ativamente suas próprias significações. Desta forma, Crary propõe que "a fotografia é um elemento de um novo e homogêneo terreno de consumo e circulação, no qual se aloja o observador. Para entender o 'efeito fotografia' do século XIX, é preciso vê-lo como componente crucial de uma nova economia cultural de valor e troca [...]. Em outras palavras, [obras de arte eram] elementos consumíveis e efêmeros em um caos cada vez maior de imagens, mercadorias e estímulos" (CRARY, 2012, p.22; 28).

Naquele início de século, marcado pelos avanços gráficos, "a facilidade crescente de acesso às imagens pelos meios impressos colaborava na formação de 'novos modos de ver' e de novas formas de relacionamento entre o homem e as imagens" (KAMINSKI, 2012, p.271). Essa relação de intimidade com as imagens e o acesso ampliado a reproduções gráficas e fotográficas se evidenciava também ou, particularmente - entre os artistas. Sabemos que João Turin, assim como outros profissionais produtores de imagens em seu tempo, teve a possibilidade de aproximar-se da fotografia não apenas como uma referência para a representação escultórica de bustos, mas também como um instrumento de divulgação e um documento de sua trajetória. Além de ser amigo e parceiro de trabalho do fotógrafo João B. Groff, ele próprio possuía uma câmera, com a qual registrava sua produção e seu ambiente de trabalho - atitudes que se tornavam cada vez mais comuns entre artistas, particularmente após a popularização da Kodak. Em especial, os registros contínuos feitos em seus atelieres ajudam a elucidar como se dava o relacionamento entre o escultor e as reproduções em papel de suas próprias obras.

Dentro do ateliê paranista que construiu na esquina entre as ruas Sete de Setembro e Coronel Dulcídio, em Curitiba, João Turin possuía uma pequena cama, sobre a qual mantinha uma espécie de painel expositor e algumas prateleiras, todos apinhados de imagens. No registro fotográfico do espaço (Figura 3), vê-se que as prateleiras superiores guardavam alguns estudos, maquetes de obras e efígies, enquanto na área ao canto acumulam-se pilhas de jornais. Imagina-se que nas páginas destes haviam inúmeras reportagens com figuras impressas, como aquelas selecionadas para ficarem penduradas ao lado direito. Já ao centro, sobre o pano preto, aparece distribuída com maior zelo uma coleção com várias ampliações fotográficas de suas obras - algumas premiadas, outras para sempre perdidas. Nessa montagem de reproduções, saliento dois registros, ambos referentes à escultura Tiradentes. Atribui-se que o primeiro destes foi feito por ele em Paris, antes da Exposição Internacional do Centenário da Independência; o segundo é provavelmente da autoria do amigo João Baptista Groff, cineasta, fotógrafo jornalístico de vários periódicos curitibanos e editor da revista Illustração Paranaense, onde ambas as imagens foram repetidamente publicadas. 


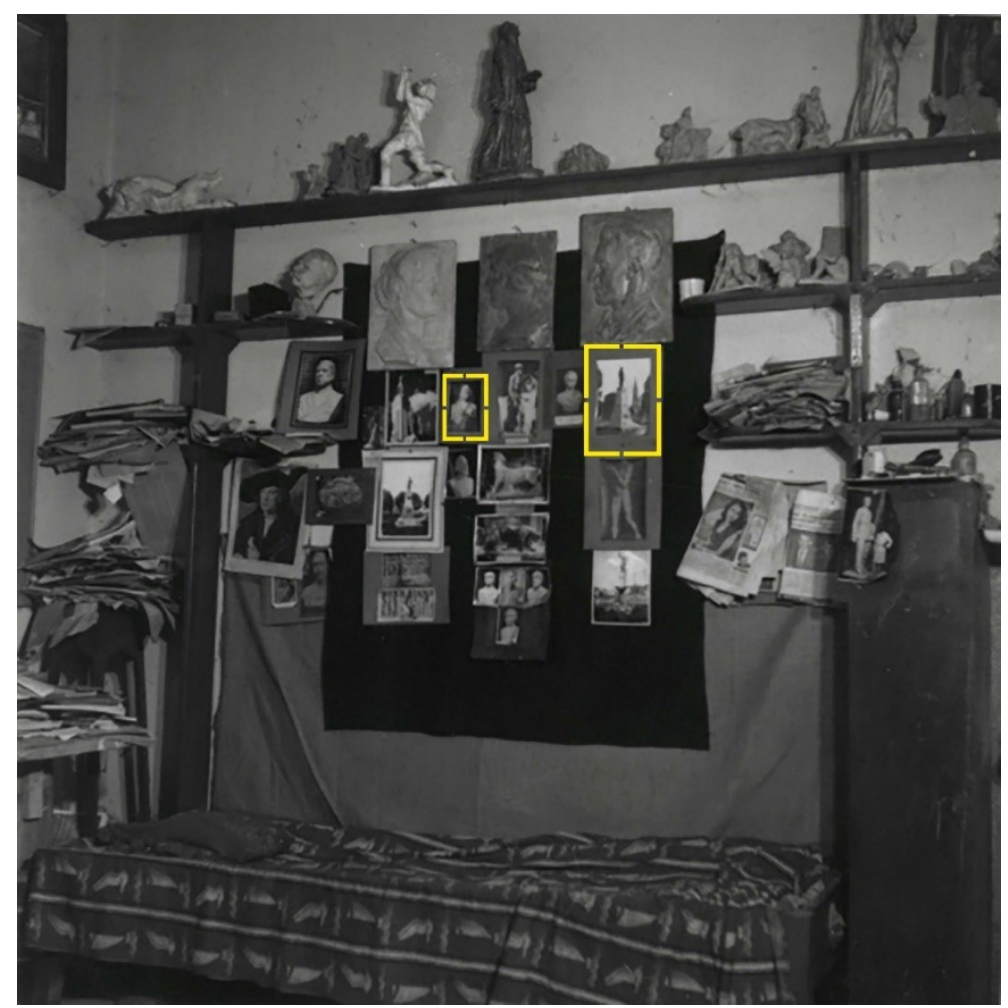

Figura 3: Cama de João Turin em seu ateliê. Fotografia. Acervo João Turin, Curitiba.

Idealizada por um grupo de intelectuais paranistas, a Illustração Paranaense, que circulou entre 1927 e 1930, foi uma publicação de conteúdos voltados às artes (locais, nacionais e estrangeiras) e atualidades (notícias e fotos das famílias da elite e do Clube Curitibano, notas sobre a política e indústria ervateira). Ou seja, a partir dela, tais agentes uniram-se para legitimar os personagens (como o pintor Alfredo Andersen ${ }^{7}$ ) e expressões culturais (como a Escola da Anta ${ }^{8}$ ) com os quais identificavam-se - além de manifestarem uma indisfarçável simpatia ao integralismo (CAMARGO, 2007, p.172). A diagramação da revista era caprichada, com textos desenhados em formatos que lembravam a araucária e o pinhão. Todas as edições eram impressas em papel de boa qualidade, adornadas por detalhes dourados e prateados, e ricamente ilustradas, com muitas fotografias e reproduções de obras de arte.

Além de ter realizado diversas ilustrações e da própria capa padrão da revista (com o "Homem Pinheiro", uma versão paranista do "Homem Vitruviano"9), João Turin era autor também de várias obras escultóricas que foram ali veiculadas - pois a produção de Turin foi extensamente registrada e valorizada por João B. Groff, na imprensa e mesmo no cinema. Especificamente, o monumento a Tiradentes parece ter sido, de longe, a obra de arte mais repetida em todas as edições da Illustração Paranaense.

No quadro comparativo (Figura 4), constata-se que a foto realizada por Turin (Figura 4A) foi reproduzida na revista diversas vezes, tendo como principal pretexto a data comemorativa do feriado de Tiradentes - pois em todos os números do mês de abril pode-se encontrar a mesma ilustrando diferentes matérias com esta temática (Figura 4B, C e D). Mas esta fotografia não circulou apenas em âmbito local. É possível encontrar uma reprodução, por exemplo, em uma montagem temática na revista carioca $O$ Malho (30/04/1932, p.17), com a legenda "busto de

\footnotetext{
${ }^{7}$ Pintor imigrante norueguês pioneiro no Paraná, professor de uma geração de artistas no início do século XX, que passou a ser cultuado como o pretenso "pai da pintura paranaense" pelos paranistas.

${ }^{8}$ Corrente conservadora e anti-modernista que surgiu em 1927 a partir do Movimento Verde-Amarelo, contrária ao Movimento Pau-Brasil. Formada por integrantes nacionalistas e fascistas, como Plínio Salgado.

${ }^{9}$ Estudo gráfico das proporções da figura humana masculina, por Leonardo Da Vinci (1490).
} 
Tiradentes, trabalho do grande esculptor Turin, em Curityba".
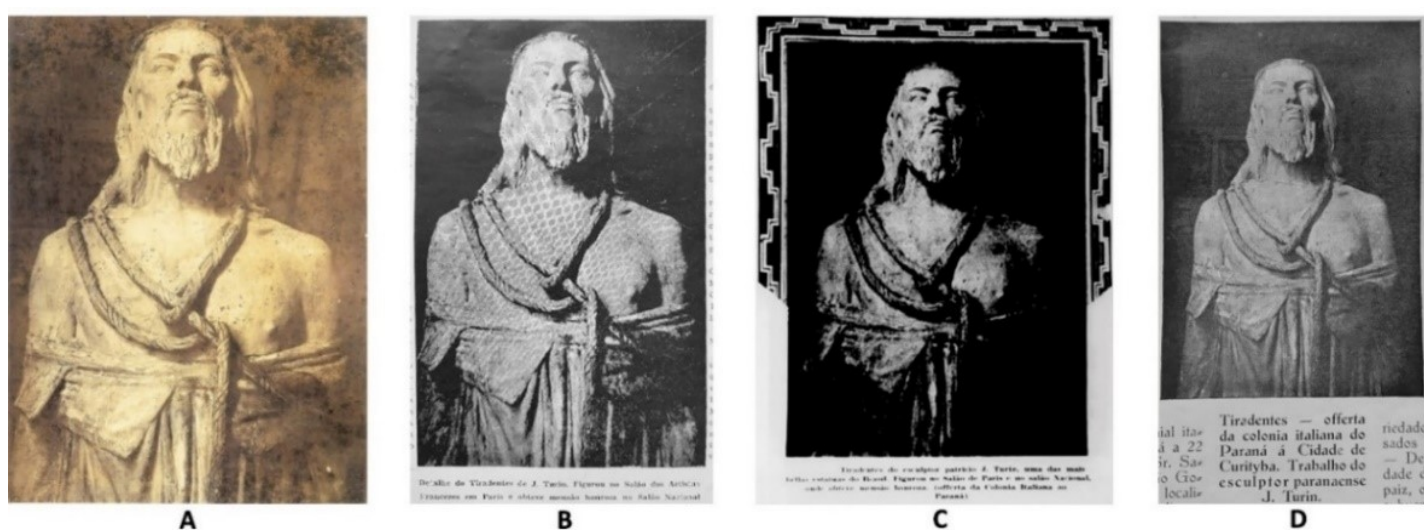

Figura 4: Fotografia da escultura Tiradentes, por João Turin, e três reproduções na Illustração Paranaense, Curitiba. (A) 1922, Acervo João Turin; (B) 1927, Biblioteca Nacional; (C) 1929, Acervo particular; (D) 1930, Acervo particular.

Além dessa, outras fotografias feitas por fotógrafos jornalísticos como João Baptista Groff, também foram veiculadas em variadas edições da revista Illustração Paranaense. Dentre elas, há os registros do monumento a Tiradentes inseridos no quadro comparativo a seguir (Figura 5). As três fotos são de datas diferentes, mas sua justaposição permite refletir sobre a experiência perceptiva do fotógrafo nos momentos dos registros, em um enquadramento lateral e levemente contra-plongée (visto de baixo), comumente utilizado por Groff nos registros de monumentos, segundo Izabel Liviski (2007), priorizando realçar o volume do objeto escultórico, de forma lírica.
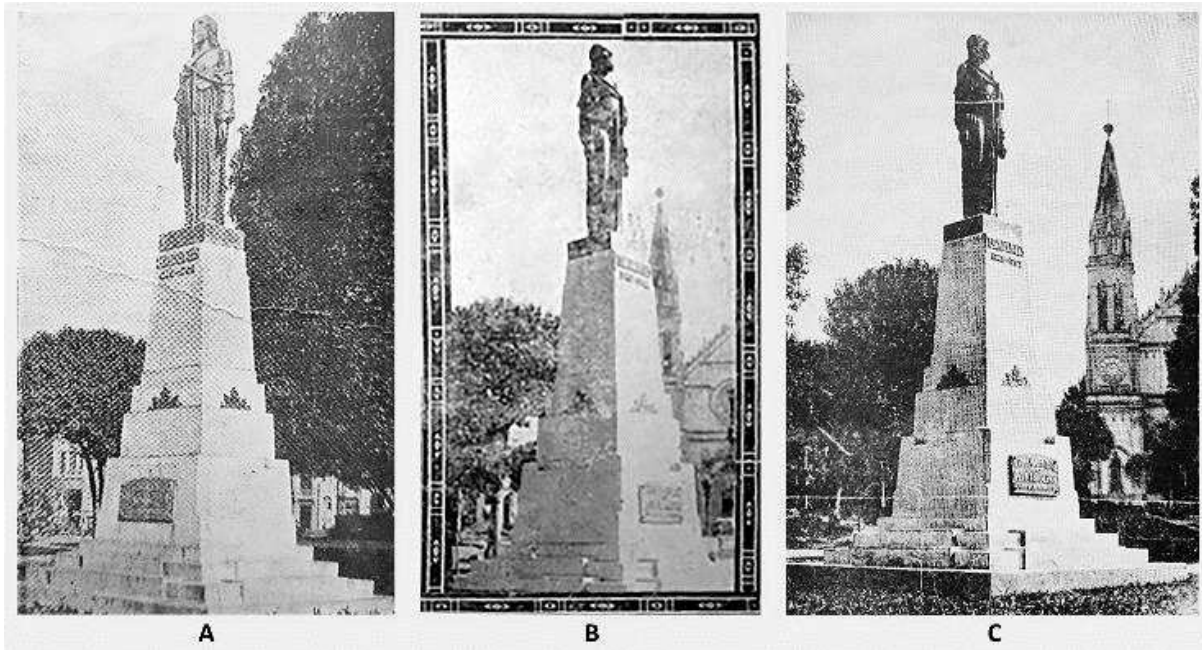

Figura 5: Reproduções gráficas de fotografias da escultura Tiradentes. Revista Illustração Paranaense, Curitiba. (A) 1930; (B) 1927; (C) 1929. Acervo particular.

Juntas, essas diferentes fotos feitas a partir do monumento oferecem uma sensação quase panorâmica, propondo uma percepção sobre a tridimensionalidade, bastante diferente daquela obtida pelo observador direto. Observadores indiretos, que têm acesso apenas às reproduções de ângulos fotográficos nas páginas das revistas, organizaram uma percepção essencialmente fotográfica sobre a tridimensionalidade de obras escultóricas, motivo pelo qual a decisão tomada durante o registro torna-se um ponto significativo. A partir dos olhos do fotógrafo e mediada pelas lentes da câmera, a presença de novas possibilidades de olhar, ainda que mais fragmentadas, reforçava a sensação de que a amplitude de reproduções aproximava o observador da imagem original. Como conceituado por Michel Frizot, a escultura é um objeto que interage com o espaço: "o conceito de escultura implica sua 
colocação em determinado espaço, uma forma apropriada de iluminação e a mobilidade do espectador" $(2014, \text { p.57, tradução nossa })^{10}$. Dessa forma, a fotografia adquire um importante papel, com a multiplicação das possibilidades de observação de um referente escultórico:

a fotografia exerce um poder em relação à escultura, [...] em particular a capacidade de repetição [...]. E isso é simplesmente o que Fox Talbot explicou em O lápis da natureza, com suas duas visões paradoxais do Busto de Pátroclo, vistas de dois ângulos diferentes e sob duas formas diferentes de iluminação. [...] a fotografia, se usada de forma sistemática e repetitiva, permite coletar todos os dados necessários para recriar um volume tridimensional na sua ausência. (FRIZOT, 2014, p.60, tradução nossa) ${ }^{11}$

Essa presença, no entanto, é subjetiva e fragmentada. Por tal razão, a experiência de encontrar-se com o objeto real, após ter formado uma imagem mental a partir de uma fotografia, por vezes acaba sendo um tanto decepcionante. Foi este, por exemplo, o estranhamento de João Turin ao ver a obra de Rodin ao vivo pela primeira vez, considerando-a "brutal e feia" (TURIN, 1998, p.110), pois sua experiência anterior havia sido mediada apenas pela percepção fotográfica. Igualmente, com o ritmo apressado das ruas, no centro da cidade de Curitiba, seria muitas vezes também pela via da reprodução técnica que o observador atentaria às imagens e identificaria a memória embrenhada na escultura de Turin, renovando o culto proposto pelo ideário político. Por outro lado, como veremos, a exposição fotográfica também teve na experiência performativa do ritual festivo a sua maior motivação.

\section{Narrativas e representações de um mártir nacional em impressos paranaenses}

No Largo da Lampadosa, Rio de Janeiro, um homem transformou a hediondez do cadafalso num altar [...]. escreveram-se duas páginas na historia patria: uma de sangue e outra de gloria! A primeira é desesperadora; é o martyrio [...]. Na segunda é a aureola de louros cingindo a fronte pura do sacrificado [...] gloria que o tempo não apagará e o manto do esquecimento jamais destruirá, é o dia de hoje, será 21 de Abril de todos os annos em que se procura cada vez mais dignificar, glorificar e respeitar a memoria sublime do Christo Brasileiro! [...] divino visionário, o idealista intemerato que defendeu o Ideal com a resignação de um santo e a bravura de um heróe, deve ser tomado como prototypo perfeito e definido dos justos [...] sobe ao cadafalso e agora que o baraço lhe preme o pescoço, escutae a sua derradeira phrase: 'Cumpri a minha palavra; morro pela liberdade!' - Agora, julgae-o e dizei si foi, ou não foi, o Christo Brasileiro! (ZICARELLI FILHO In: O Dia, 22/04/1927, p.2)

Na página seguinte à capa do dia 22 de abril de 1927, que apresentava Tiradentes como o "grande mártir" nacional, foi publicado um texto de Francisco Zicarelli Filho intitulado "Christo Brasileiro". Em sua longa e devotada argumentação, ele se propunha a levantar o máximo de pontos em comum que conseguisse inferir entre as histórias de Joaquim José da Silva Xavier e Jesus Cristo; comprava as narrativas republicanas e apropriava-se do imaginário presente nas inúmeras representações artísticas criadas até então - como se ambas as referências significassem testemunhos inquestionáveis do passado. Sobressaem em seu texto diversos termos provenientes da religião católica (altar, auréola, divino, santo, crucifixo, manto) e outros tantos que se propunham a caracterizar uma figura heroica

\footnotetext{
${ }^{10}$ No original: "the concept of sculpture implies its placement in a given space, an appropriate form of lighting, and the mobility of the viewer."

${ }^{11}$ No original: "photography exerts a power in relation to sculpture, [...] in particular the faculty of repetition [...]. And this is quite simply what Fox Talbot explained in The Pencil of Nature with its two paradoxical views of the Bust of Patroclus, seen from two different angles and under two different forms of lighting. [...] photography, if used in a systematic and repetitive way, allows us to collect all the data needed to recreate a three-dimensional volume in its absence".
} 
(sangue, martírio, sacrifício, herói, perfeito, sereno), com a intenção de confundir, justamente, a imagem de Tiradentes à de Cristo.

Nenhuma dessas analogias encontradas no jornal curitibano era, de longe, original: a associação entre as figuras de Tiradentes e Jesus teve início já no século XIX, com um poema de Castro Alves, de 1866, intitulado "Cristo da multidão", que ao longo do tempo viria a inspirar muitos outros autores e artistas. Segundo José Murilo de Carvalho, isto fazia parte da estratégia de mitificação do herói, em razão do perfil cristão dos brasileiros. Sobre isto, o autor também expressa que:

em vez da forca, tornada altar da pátria, construíram um monumento. Em vez da tragédia do martírio, exibiram a comédia da estátua [...]. [A partir] da própria tradição oral, as representações plásticas e literárias de Tiradentes, e mesmo exaltações políticas, passaram a utilizar cada vez a simbologia religiosa e a aproximá-lo da figura de Cristo. [...] Um artigo de 1888, escrito por republicanos mineiros, chegava a atribuir a Tiradentes maior fortaleza moral do que a de Cristo. Ele teria recebido com maior serenidade a sentença (CARVALHO, 2014, p.66-69)

No âmbito visual, este aspecto é notório. O desconhecimento sobre a aparência do personagem inconfidente era muito oportuno para artistas acadêmicos e positivistas, como Décio Villares (em 1890), que puderam usar suas próprias interpretações no processo de mitificação. Carvalho (2014, p.76) apresenta, por exemplo, as colocações do político e intelectual republicano Ubaldino do Amaral, que teria observado: "nenhum teve razão, todos tiveram razão, porque é assim que as lendas se fazem".

Muitos artistas brasileiros trataram de representar Tiradentes à semelhança de como entendiam a aparência de Cristo $^{12}$ : com inspiração nos cabelos longos, a barba, o manto, os pés descalços, as feições e gestos das mãos. Ao analisar, por exemplo, o monumento assinado por Virgílio Cestari (1891-1894), em Ouro Preto, José Murilo de Carvalho (2014, p.76) observa como a figura foi projetada para parecer a de um profeta, um semideus, em seu porte altivo. Algo semelhante parece ter sido feito com o monumento de Francisco Andrade (1926), no Rio de Janeiro. Ademais, para além das obras escultóricas, essa tendência também se manifesta na pintura, como na obra $O$ martírio de Tiradentes, por Aurélio de Figueiredo (Figura 6), onde aparecem ainda outros índices do martírio: o crucifixo, o pombo branco e a corda do próprio enforcamento (assumindo então o caráter de relíquias).

\footnotetext{
${ }^{12}$ De acordo com Cartlidge e Elliott (2001, p.47-73) não há definição bíblica sobre a aparência de Cristo. Na realidade, há escritos que indicam sua possível transfiguração em diferentes aparências, porém sem descrições exatas. Deste modo, a representação artística de sua físionomia tornou-se uma questão retórica e foi, também, elaborada historicamente, e especialmente reforçada pela circulação das primeiras fotografias do "Sudário de Turim", em 1898.
} 


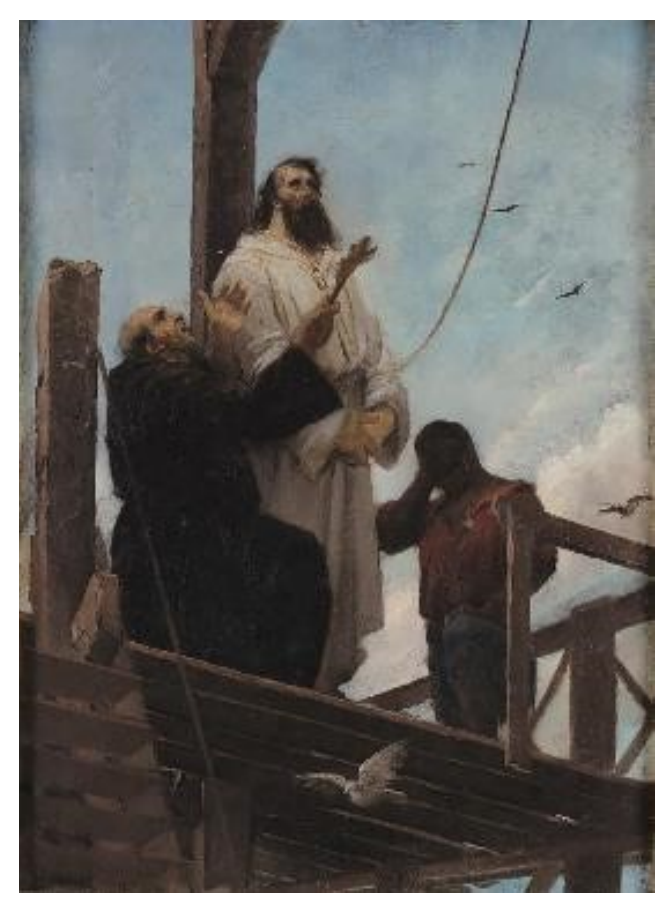

Figura 6: Aurélio de Figueiredo, O martírio de Tiradentes, 1893. Óleo sobre tela, 57 x $45 \mathrm{~cm}$. Museu Histórico Nacional, Rio de Janeiro.

Essa face cristianizada foi amplamente reproduzida desde o século XIX, como uma efígie oficial do personagem. Um exemplo de seu uso pedagógico pode ser encontrado na capa do dia 21 de abril do jornal O Dia (Figura 7), onde encontram-se justapostas diversas reproduções feitas a partir de fotos de obras de arte. Dentre elas, uma informa em caráter ilustrativo como seria a face de Tiradentes, para que este fosse reconhecido nas outras figuras. Também é apresentado ao leitor o retrato de João Turin. Na mesma capa, logo abaixo da manchete, há um outro par de imagens a ser notado: a aproximação do monumento de Turin à cena pictórica de Aurélio de Figueiredo. Sobre essas fotografias, as legendas "hontem" e "hoje" sugerem uma sequência proselitista, parecida com a narrativa da Paixão: o martírio do homem em seu cadafalso e a ressurreição do herói em seu pedestal. 


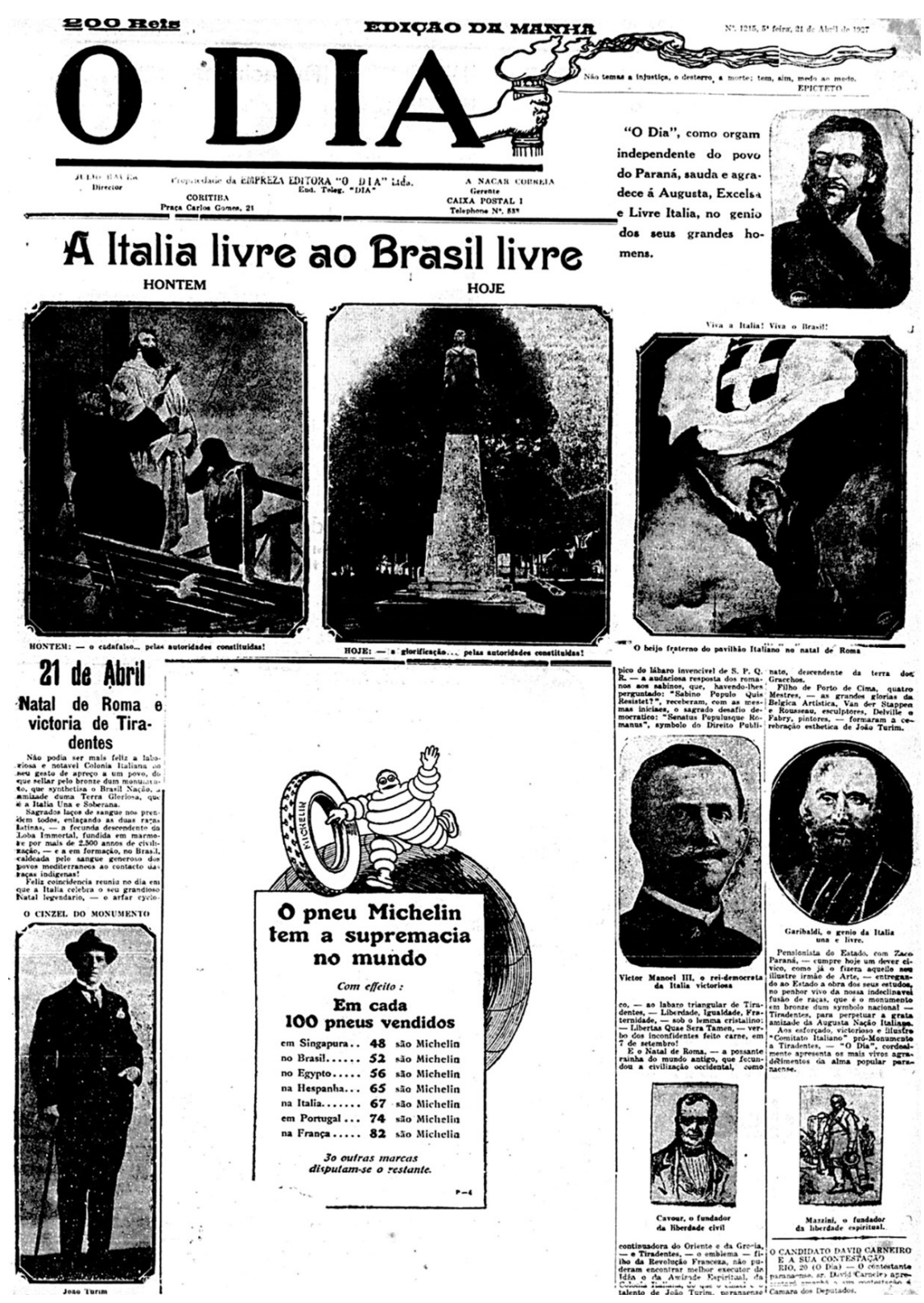

Figura 7: O Dia, no 1215, 21 de abril de 1927, p.1. Hemeroteca da Biblioteca Nacional.

Para além das reproduções de obras de arte, encontra-se na mesma capa uma imagem nacionalista com a bandeira do Império Italiano; e uma publicidade da Michelin, com uma palavra-chave proeminente no desenrolar do século XX: a supremacia. O jornal, portanto, sugeria aos leitores o tom daquilo que deveriam compreender sobre o evento - apresentava aos paranaenses sua versão de quem foi o mártir, quem fez a imagem para a adoração, quem foi o responsável pelo altar simbólico e a que ideais morais e políticos isto estava atrelado.

Sobre a trajetória das representações de mártires na Arte, cumpre observar que a iconografia do sofrimento é uma temática de longa linhagem, segundo Susan Sontag, destinada à contemplação com o objetivo de comover, estimular, instruir e dar exemplos morais (SONTAG, 2003, p.37). Da mesma forma, para Maraliz Christo, esta categoria temática da pintura propõe uma desconstrução da imagem do herói, antes ligada a figuras de poder, substituindo-a por homens solitários, anônimos e vencidos, vilipendiados e condenados (CHRISTO, 2005, p.4). Sublinha-se que o papel moralizante introjetado pela narrativa de um personagem-mártir também serviria aos interesses políticos vigentes. Os artistas alinhados à Academia durante a República detinham, na pintura histórica por exemplo, o papel de 
realizar uma espécie de nova cenografia política. Da mesma forma, artistas que estavam à margem do sistema acadêmico brasileiro, como João Turin, mas que trabalhavam a serviço do Estado na elaboração de monumentos escultóricos encomendados também assumiram esse papel. Estas não se tratavam simplesmente de representações imagéticas sobre política, mas consistiam no próprio ato político (GINZBURG, 2014, p.49).

Sobre este aspecto, Paulo Knauss observou que, no processo de subscrição e inauguração da escultura pública, ela está sempre atrelada à lógica monumental, com finalidades didáticas e celebrativas, pela "construção de uma memória socialmente elaborada em torno do passado histórico" (KNAUSS, 2000, p.407). Dentro desta lógica, a própria mobilização social em torno da imagem completava uma verdadeira "festa da imagem", onde a relevância e o caráter cívico da escultura eram definidos pelo próprio rito (KNAUSS, 2008, p.179). Aqui, adiciono que além da ação performativa, poderíamos incluir também a própria promoção da escultura em reproduções fotográficas que se faziam circular e reverberar, muito tempo depois do tempo específico do rito: uma festa fotográfica permanente.

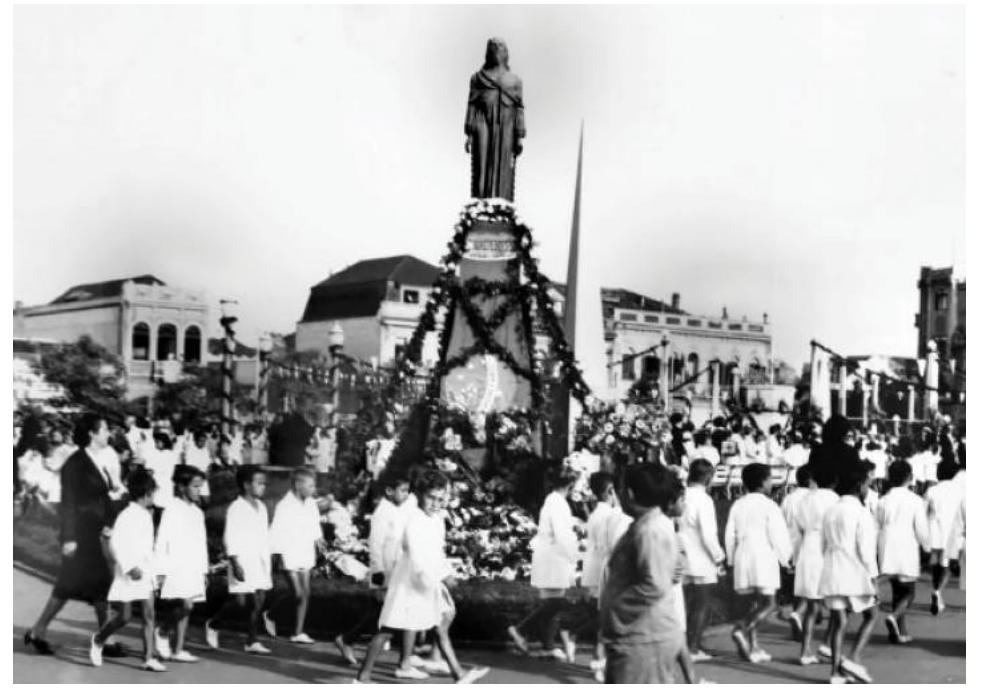

Figura 8: Cerimônia festiva ao monumento Tiradentes, 1927. Fotografia. Acervo João Turin, Curitiba.

Em fotografias feitas durante a inauguração do monumento a Tiradentes (Figura 8), é inevitável perceber que a aproximação festiva entre o espectador e a imagem escultórica é semelhante ao encontrado nos rituais de culto religioso católico, justamente - e que a tridimensionalidade parecia intensificar mais, de certa forma, a percepção de uma forte presença física do mártir. A escultura de João Turin, elevada sobre a bandeira do Brasil, aparece adornada de flores, e homenageada por disciplinados estudantes que desfilavam junto a uma multidão devota do personagem nacional.

O feriado de Tiradentes inspiraria a persistência da celebração cívica sobre esta escultura nas décadas subsequentes. Podemos observar em fotografias que a presença de adornos festivos envolvidos na imagem continuaria a ser reempregada. Mesmo no século XXI, o monumento continuou a ser ponto de interesse para veneração e realização de novas imagens fotográficas, reiterando sentidos acumulados através dos tempos, como demonstrado na foto veiculada em 2014 pela Gazeta do Povo, na ocasião da recolocação da estátua em seu pedestal após restauro (Figura 9). Também recentemente, a imagem foi assunto de outra reportagem jornalística, após a curiosa constatação de que uma escultura pública existente em Ponta Grossa (Figura 10) era a réplica exata, não autorizada, da obra de Turin, cujo molde teria sido feito sorrateiramente na década de 1970, a partir do próprio original (CORDEIRO, 2013). 

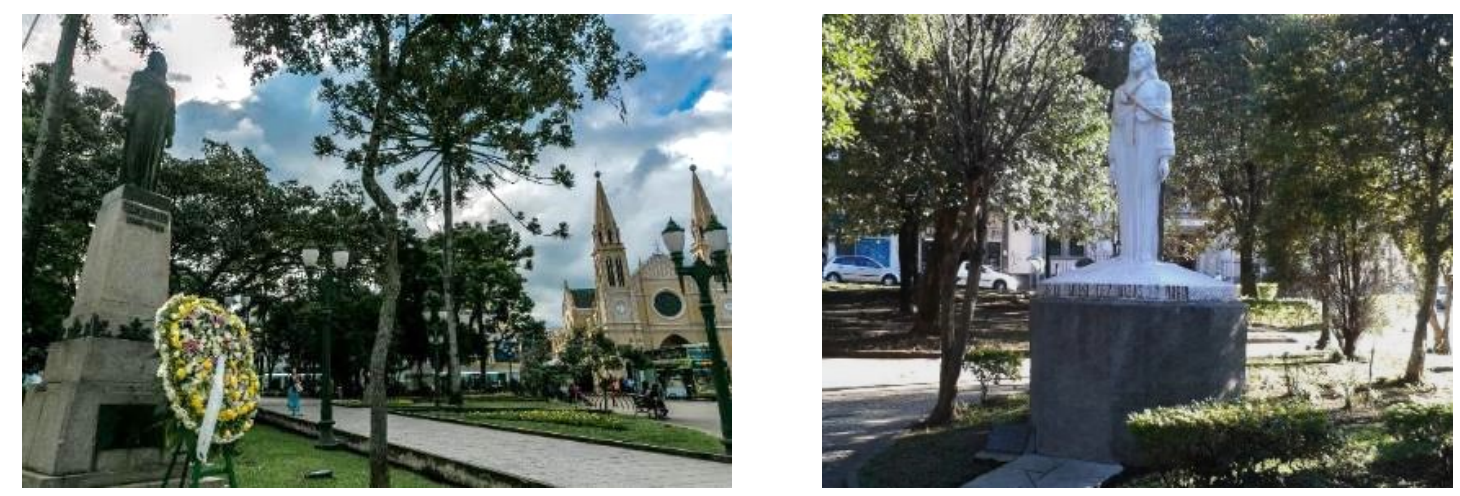

Figura 9: Escultura recolocada na praça após restauro. Fotografia de Maurilio Cheli. Gazeta do Povo, 21/04/2014.

Figura 10: Réplica não autorizada da escultura Turin. Fotografia de Silvia Cordeiro. G1, 31/07/2013.

É importante considerar, ainda, que a narrativa sobre Tiradentes foi empregada como motivo político de maneira ampla e frequente durante todo o século XX. De acordo com José Murilo de Carvalho (2017, p.78), no Estado Novo o governo ofereceu apoio a peças de teatro educativas com a temática. Posteriormente, em plena ditadura militar, segundo Artur Freitas (2013, p.224), a memória do mártir se tornou terreno de disputas entre vertentes políticas à esquerda e à direita - e, embora com interesses ideológicos contrários entre si, ambas as representações tendiam à sua monumentalização simbólica. À direita, apropriaram-se do personagem como uma espécie de patrono cívico da nação, com a inserção de seus retratos em todas as grandes repartições públicas. À esquerda, o Teatro de Arena associou o inconfidente à atitude subversiva. Realizou-se ainda, à época, a polêmica obra de arte Tiradentes: Totem-Monumento ao preso político, de Cildo Meireles (em 1970), que envolvia uma chocante queima de galinhas vivas, com o objetivo de apontar criticamente os usos políticos das discrepantes narrativas sobre Tiradentes, no contexto violento dos "anos de chumbo".

Por fim, também a memória sobre o autor da escultura aqui analisada, João Turin, continuaria a ser reiterada e fortalecida pelo campo cultural de Curitiba após sua morte, em 1949, incluindo sempre a fotografia. O intelectual Erasmo Pilotto publicou uma homenagem ao artista ainda em 1952, com reproduções de algumas obras. Em 1989, foi noticiada a constituição do acervo da Casa João Turin, pela Fundação Cultural de Curitiba, em comodato com os seus herdeiros, e no ano de 1998 foi publicado o livro ilustrado de memórias de Elisabete Turin, sobrinha-neta do escultor. No entanto, as atividades daquele museu foram encerradas em 2012, e o acervo foi vendido para o colecionador Samuel Lago. Em 2014 realizou-se uma grande exposição no olho do Museu Oscar Niemeyer, de curadoria de José Roberto Teixeira Leite, com destaque especial para o monumento a Tiradentes, alocado logo na entrada. Seriam publicados também um catálogo e um website sobre a coleção ${ }^{13}$. Finalmente, em 2021, quase um século depois da concepção da escultura de Tiradentes, foi aberto no Parque São Lourenço o "Memorial Paranista"14, e na ocasião a Gazeta do Povo publicou a curiosa manchete-slogan "Curitiba inaugura maior jardim de esculturas do Brasil" (GALANI, 2021), ladeada às fotografias de Maringas Maciel. O local, erguido com o intuito de celebrar o movimento cívicocultural do qual participara Turin na década de 1920, conta com 78 obras, 15 ampliações em bronze acomodadas no pátio e um intenso apelo à realização de selfies, disseminado pelas redes sociais.

\section{Considerações finais}

Com a ampla visibilidade fotográfica recebida pela escultura de Turin em meios impressos, o que seria inicialmente uma peça para os salões de arte, tornou-se um monumento cívico e passou a transitar e se metamorfosear também de forma bidimensional nas revistas como uma narrativa festiva de si mesma. A repercussão fotográfica da escultura Tiradentes se trata de um proveitoso exemplo

\footnotetext{
${ }^{13}$ Disponível em: João Turin <joaoturin.com.br>.

${ }^{14}$ Disponível em: Memorial Paranista - Prefeitura de Curitiba < curitiba.pr.gov.br/memorialparanista $>$.
} 
do uso da cópia fotográfica como meio de circulação de objetos tridimensionais, promovendo artistas que atuaram na virada entre os séculos XIX e XX, como João Turin. A fotografia presta-se desde sua invenção à ampliação de percepções e da circulação da escultura, os quais inspiram inúmeros questionamentos e merecem ainda um aprofundamento na historiografia das imagens.

Considerando que a apreensão fotográfica de uma escultura é relativa à reconstrução possível de uma consciência em relação aos estímulos visuais alcançados pelo observador-fotógrafo, além da delimitação do tempo e espaço diretamente percorridos no entorno da obra durante o registro, as informações visuais podem sobrepor-se também a impressões obtidas anteriormente, em outras experiências, ou mesmo mediante outras imagens de um repertório rememorado. Uma imagem pode completar a apreensão de outra, e contribuir para a construção mental da experiência escultórica.

Foi justamente com o intermédio da imagem técnica que se completou o processo de visibilidade e celebração do personagem escultórico analisado neste artigo. A obra de Turin dialogava com muitas outras imagens artísticas que corporificavam o mártir Tiradentes desde o século XIX (com uma feição cristianizada) e permitia que este pudesse ser venerado e cultuado pelo coletivo popular, passando, efetivamente, do âmbito da imaginação para a materialidade visível. Mas a circulação das reproduções fotográficas da escultura de João Turin em jornais e revistas modificava não apenas a percepção de um observador sobre o monumento como também colaborava para intensificar o culto ao personagem e à própria obra de arte. A partir deste caso, podem ser considerados, portanto, dois importantes papéis para a fotografia impressa em seu encontro com esta escultura: primeiro, enquanto instrumento de manutenção da ritualização; e, segundo, como recurso de ampliação das percepções possíveis no entorno do objeto tridimensional. A escultura, enfim, circula e se remodela por meio da objetiva, transfigura-se em uma nova linguagem.

\section{Referências}

AGULHON, Maurice. La 'statuomanie' et l'histoire. Histoire vagabonde: etnologie et politique dans la France contemporaine. v.1. Paris, Gallimard, 1988.

AMARAL, Aracy. Artes plásticas na semana de 22. São Paulo: Ed. 34, 1998.

BENJAMIN, Walter. A obra de arte na era de sua reprodutibilidade técnica. In: Benjamin e a Obra de Arte: Técnica, imagem e percepção. Rio de Janeiro: Contraponto, 2012.

CAMARGO, Geraldo Leão. Esculturas públicas em Curitiba e a estética autoritária. Revista Sociol. Polít., Curitiba, 25, nov. 2005. p.63-82.

CAMARGO, Geraldo Leão. Paranismo: Arte, ideologia e relações sociais no Paraná (1853-1953). Tese (Doutorado em História). UFPR. Curitiba, 2007.

CARTLIDGE, David; ELLIOTT, J. Keith. Images of the Christ. In: Art and the Christian Apocrypha. Londres: Routledge, 2001.

CARVALHO, José Murilo de. A formação das almas: o imaginário da República no Brasil. São Paulo: Cia das Letras, 2017.

CHRISTO, Maraliz de Castro Vieira. Pintura, história e heróis no século XIX: Pedro Américo e 'Tiradentes Esquartejado'. Tese (Doutorado em História). Unicamp. Campinas, 2005.

CORDEIRO, Silvia. Acervo de João Turin diz que estátua de Tiradentes é réplica não autorizada.

G1 Paraná. Ponta Grossa. 31 jul. 2013. Disponível em: $<$ http://glo.bo/14DWgCS $>$

CRARY, Jonathan. Técnicas do observador. Rio de Janeiro: Contraponto, 2012.

Diário da Tarde. Ano 29, nº 9821. Curitiba. 21 abr. 1927. Biblioteca Nacional. 
Diário da Tarde. Ano 29, nº 9790. Curitiba. 15 mar 1927. Biblioteca Nacional.

DOLCI, Mariana. Personagem imortal: construção da memória de Tiradentes no Museu Paulista e no Museu da Inconfidência. Dissertação (Mestrado em História Social). PUCSP. São Paulo, 2014.

FREITAS, Artur. Arte de guerrilha: vanguarda e conceitualismo no Brasil. São Paulo: USP, 2013.

FRIZOT, Michel. Sculpture, between visual perception and photography. In: ECKER; KUMMER; MALSCH; MOLDERINGS (Orgs.). Lens-Based Sculpture. Berlim: Akademie der Künste, 2014.

GALANI, Luan. Curitiba inaugura maior jardim de esculturas do Brasil e memorial com quase 100 obras de João Turin. Gazeta do Povo, 14 mai. 2021. Disponível em: <bityli.com/naTq4>

GINZBURG, Carlo. Medo, Reverência e Terror. São Paulo: Companhia das Letras, 2014.

KAMINSKI, Rosane. Gosto brejeiro: as revistas ilustradas e a formação de juízos estéticos em Curitiba (1900-1920). In: BREPOHL; CAPRARO; GARRAFFONI (Orgs.). Sentimentos na história. Curitiba: Ed. UFPR, 2012.

KNAUSS, Paulo. Imaginária urbana: Escultura pública na paisagem construída do Brasil. In: SALGUEIRO, Heliana Angotti (coord.). Paisagem e arte. São Paulo: CBHA, 2000.

KNAUSS, Paulo. A festa da imagem: a afirmação da escultura pública no Brasil do século XIX. In: CAVALCANTI, Ana; DAZZI, Camila; VALLE, Arthur (Orgs.). Oitocentos: Arte brasileira do Império à Primeira República. Rio de Janeiro: EBA-UFRJ; DezenoveVinte, 2008.

LEITE, José Roberto Teixeira. João Turin: vida, obra, arte. Curitiba: Nossa Cultura, 2014.

LIVISKI, Izabel. Leituras da urbanização e da construção da identidade paranaense na fotografia de João Baptista Groff. Dissertação (Mestrado em Sociologia). UFPR. Curitiba, 2007.

MAUAD, Ana Maria. Como nascem as imagens? Um estudo de história visual. História: Questões \& Debates, v. 61, n. 2, 2014.

O Dia. Curitiba, 19 Fev. 1927. Biblioteca Nacional.

O Dia. Curitiba, 17 Abr. 1927. Biblioteca Nacional.

O Dia. Curitiba. 21 Abr. 1927. Biblioteca Nacional.

O Dia. Curitiba, 22 Abr. 1927. Biblioteca Nacional.

O Malho. Ano XXI, no 1058. Rio de Janeiro, 23 Dez. 1922. Biblioteca Nacional.

O Malho. Ano XXI, no 1059. Rio de Janeiro, 30 Dez. 1922. Biblioteca Nacional.

O Malho. Ano XXXI, no 1532. Rio de Janeiro, 30 Abr. 1932. Biblioteca Nacional.

PEREIRA, Luis Fernando Lopes. Paranismo: Cultura e Imaginário no Paraná da I República. Dissertação (Mestrado em História). UFPR. Curitiba, 1996.

SANT'ANA, Thaís. A Exposição Internacional do Centenário da Independência: modernidade e política no Rio de Janeiro do início dos anos 1920. Dissertação (Mestrado em História). Unicamp: Campinas, 2008.

SONTAG, Susan. Diante da dor dos outros. São Paulo: Companhia das Letras, 2003.

TURIN, Elisabete. A arte de João Turin. Campo Largo: INGRA, 1998.

TURIN, João Zanin. Documentos Manuscritos do Arquivo João Turin. Coleção Samuel Lago. N.d.

VELLOSO, Mônica; OLIVEIRA, Lúcia; GOMES, Ângela Castro. Estado Novo: Ideologia e poder. Rio de Janeiro: Zahar, 1982. 